\title{
PENCARIAN POLA ASOSIASI UNTUK PENATAAN BARANG DENGAN MENGGUNAKAN PERBANDINGAN ALGORITMA APRIORI DAN FP- GROWTH (STUDY KASUS DISTRO EPO STORE PEMALANG)
}

\author{
ASSOCIATION PATTERN MINING FOR PRODUCT ARRANGEMENT USING \\ COMPARISON BETWEEN APRIORI ALGORITHM AND FP-GROWTH (CASE \\ STUDY AT EPO STORE DISTRIBUTION STORE IN PEMALANG)
}

\author{
Abu Salam ${ }^{1}$, Junta Zeniarja ${ }^{2}$, Wibowo Wicaksono ${ }^{3}$, Lutfi Kharisma ${ }^{4}$ \\ ${ }^{1,2,3}$ Universitas Dian Nuswantoro; J1. Nakula I No 5 - 7 Semarang,50131, Telp (024)3515261 \\ Jurusan Teknik Informatika, Fakultas Ilmu Komputer Udinus, Semarang \\ e-mail: ${ }^{1}$ abu.salam@dsn.dinus.ac.id, ${ }^{2}$ junta.zeniarja@dsn.dinus.ac.id, ${ }^{3}$ wicaksono.mkom@ gmail.com, \\ ${ }^{4} 111201408157 @$ mhs.dinus.ac.id
}

\begin{abstract}
Abstrak
Analisis keranjang pasar merupakan study tentang proses analisis untuk mencari sebuah aturan asosiasi dalam mencermati pola-pola pembelian konsumen pada setiap transaksi penjualan, pola-pola pembelian yang sudah di dapat dari pencarian dataset kemudian dapat digunakan untuk merencakan strategi penjualan seperti harga diskon jika membeli barang A dan B atau menunjukan tata letak pada barang yang ditemukan pada proses pencarian pola asosiasi yang menghasilkan aturan asosiasi, pola asosiasi sendiri memiliki beberapa metode untuk mencari aturan asosiasi dan yang sering dipakai dalam pencarian aturan asosiasi adalah Apriori dan FP-Growth dimana kedua metode ini menghasilkan aturan asosiasi dengan tingkat lift ratio yang tinggi dimana jika lift ratio bernilai $>1$ sudah dinyatakan valid sehingga semakin besar tingkat lift ratio pada aturan asosiasi yang ditemukan maka akan semakin kuat aturan asosiasi tersebut, pada penelitian ini penulis melakukan pencarian aturan asosiasi pada data penjualan epo store pada bulan November, Desember 2017 dan Januari 2018, dengan menggunakan dua metode pencarian asosiasi yaitu apriori dan FP-Growth untuk membandingkan metode mana yang lebih baik dalam pencarian aturan asosiasi serta untuk melakukan perencanaan penjualan berupa tata letak dari metode yang memiliki tingkat lift ratio tertinggi.
\end{abstract}

Kata Kunci : aturan asosiasi, FP-Growth, Apriori, Epo Store, lift ratio

\begin{abstract}
The Market base analysis is a study about process analysis to find an association rule to observe the patterns of consumers buying in every selling transaction. The selling patterns took by finding a dataset, then it can be used to plan to sell strategy like giving discount price if they bought product $A$ and $B$. it also to show a layout of products which found in the process association pattern that produce association rule. The association pattern itself has some method to find association rule and the usual association process for this is Apriori and FP-Growth. These methods produced association rule with higher lift ratio level if lift ratio has value $>1$ clarified as valid, so the higher lift ratio level in the association rule then these association rule will be stronger. In this research, the writer did the finding of association rule for selling data of EPO Store at in November, December 2017 and January 2018, by using two methods of finding an association, Apriori and FPGrowth, to compare which the better method for finding association rule. It also to make selling planning to determine the layout of the method which has the highest lift ratio.
\end{abstract}

Keywords: association rule, FP-Growth, Apriori, Epo Store, lift ratio 


\section{PENDAHULUAN}

Dewasa ini, kemajuan teknologi sudah sangat maju hampir di dalam semua bidang pekerjaan dan kegiatan manusia sehari-harinya telah dibantu oleh teknologi[1]. Salah satu bidang teknologi yang membantu manusia adalah teknologi informasi banyak study tentang teknologi informasi yang dapat membantu kegiatan manusia di zaman teknologi ini salah satunya adalah data mining dengan teknik assosiation rule untuk menganalisis keranjang pasar atau biasa juga disebut market basket analysis [2]. Untuk menganalis keranjang pasar pengelola harus mencermati pola-pola pembelian konsumen pada setiap transaksi yang harus dicatat yang nantinya akan sangat berguna bagi para penjual [3].

Assosiation rule sendiri merupakan teknik data mining untuk menemukan aturan asosiatif antara suatu kombinasi item [4], sehingga Assosiation rule merupakan teknik data mining yang dapat menganalisis keranjang pasar pada data penjualan sehingga dapat ditemukan kombinasi item yang sering dibeli oleh pelanggan.

Metode association rule memiliki 2 algoritma yang sering digunakan pada pencarian pola itemset yaitu algoritma apriori dan FP-Growth [5] dimana kedua algoritma tersebut sering digunakan untuk mencari pola asosiasi pada suatu produk yang muncul dalam satu data [6].

Dari pertimbangan kedua algoritma tersebut penulis akan melakukan penelitian tentang pencarian pola Association Rule untuk melakukan penataan barang dengan mengambil objek dari toko pakaian distro Epo Store yang beralamat di jalan raya kartini,Kecamatan Petarukan Kabupaten Pemalang, Jawa Tengah.

Dengan mengambil sample data transaksi penjualan pakaian distro, penulis akan membandingkan algoritma mana yang lebih baik untuk menganalisis pola assosciation rule untuk mendapatkan pola item set. Diharapkan hasil pola itemset dengan membandingkan dua algoritma aprirori dan fp-growth dapat bermanfaat untuk membantu Epo Store dalam mengatasi strategi penjualannya.

\section{METODE PENELITIAN}

Untuk melakukan pencarian asosiasi terhadap data penjualan epo store tahapan yang perlu dilakukan untuk mendapatkan hasil pengujian yang terbaik. Berikut ini adalah tahapan yang dilakukan dalam penelitian aturan asosiasi.

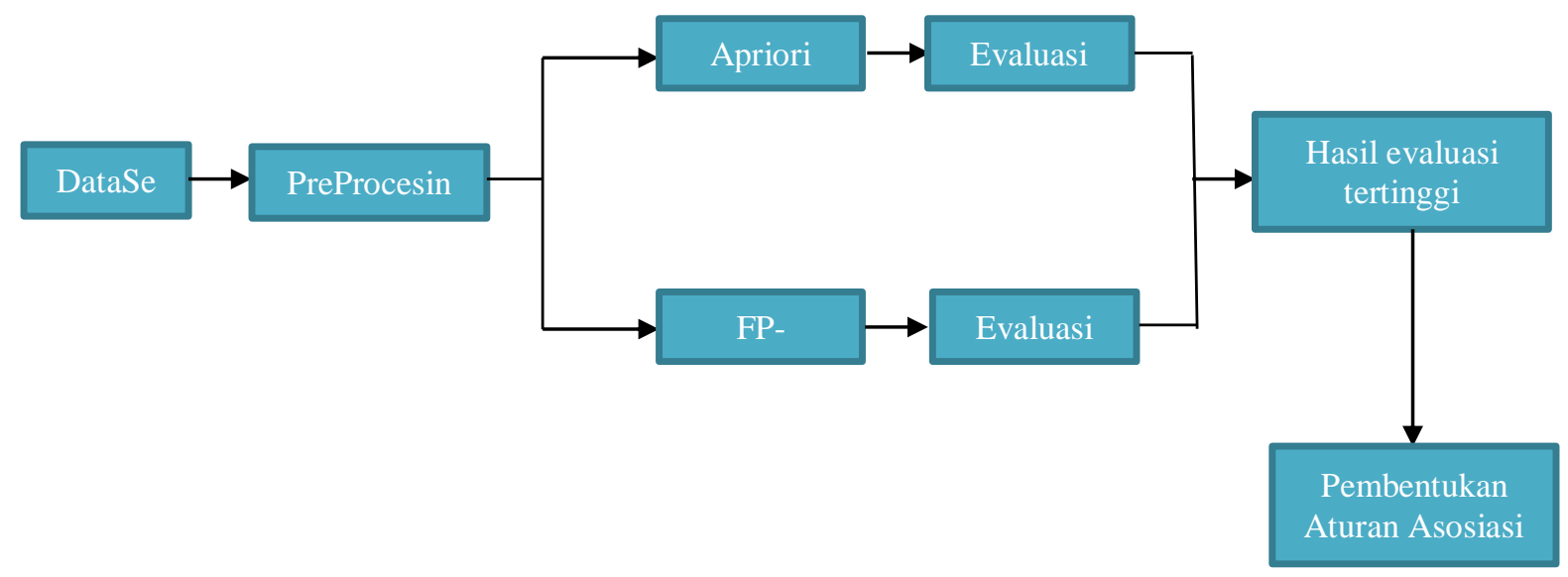

Gambar 1. Metode Penelitian

\subsection{Dataset}

Dataset yang digunakan adalah data penjualan bulan November, Desember 2017 dan Januari 2018 seperti pada contoh gambar 2 tampilan data penjualan Epo Store. 
Tabel 1. Data Penjualan

\begin{tabular}{|c|c|c|c|c|c|c|c|c|c|c|}
\hline & A & B & C & D & E & $\mathrm{F}$ & & G & $\mathrm{H}$ & 1 \\
\hline 1 & \multicolumn{10}{|c|}{ LAPORAN PENJUALAN EPPO STORE TAHUN 2017} \\
\hline 2 & tanggal & No struk & Nama Barang & Jenis & Merek & Transaksi & & Harga & diskon & Harga Jual \\
\hline 3 & $01 / 11 / 2017$ & 00001 & kaos pendek fucking enemy & kaos pendek & fucking enemy & penjualan & $\mathrm{Rp}$ & 75.000 & $10 \%$ & Rp 67.500 \\
\hline 4 & $01 / 11 / 2017$ & 00001 & jaket bomber prapatan rebel & Jaket bomber & Prapatan rebel & penjualan & $\mathrm{Rp}$ & 135.000 & $10 \%$ & Rp 121.500 \\
\hline 5 & $01 / 11 / 2017$ & 00002 & tas $\mathrm{x}$ radius & tas & $\mathrm{x}$ radius & penjualan & $\mathrm{Rp}$ & 140.000 & $10 \%$ & Rp 126.000 \\
\hline 6 & $01 / 11 / 2017$ & 00003 & kaos pendek memphis origin & kaos pendek & memphis origin & penjualan & $\mathrm{Rp}$ & 70.000 & $10 \%$ & Rp 63.000 \\
\hline 7 & $01 / 11 / 2017$ & 00003 & kaos lengan panjang seventh angel & kaos panjang & seventh angel & penjualan & $\mathrm{Rp}$ & 90.000 & $10 \%$ & Rp 81.000 \\
\hline 8 & $01 / 11 / 2017$ & 00003 & kaos pendek fucking enemy & kaos pendek & fucking enemy & penjualan & $\mathrm{Rp}$ & 75.000 & $10 \%$ & Rp $\quad 67.500$ \\
\hline 9 & $01 / 11 / 2017$ & 00004 & Jaket hoody fucking enemy & jaket hoody & fucking enemy & penjualan & $\mathrm{Rp}$ & 120.000 & $10 \%$ & Rp 108.000 \\
\hline 10 & $01 / 11 / 2017$ & 00005 & kaos lengan panjang gangster & kaos panjang & gengster & penjualan & $\mathrm{Rp}$ & 80.000 & $10 \%$ & Rp 72.000 \\
\hline 11 & $01 / 11 / 2017$ & 00005 & kaos lengan panjang seventh angel & kaos panjang & seventh angel & penjualan & $\mathrm{Rp}$ & 90.000 & $10 \%$ & Rp 81.000 \\
\hline 12 & $01 / 11 / 2017$ & 00005 & kaos pendek farodist & kaos pendek & farodist & penjualan & $\mathrm{Rp}$ & 75.000 & $10 \%$ & Rp $\quad 67.500$ \\
\hline 13 & $01 / 11 / 2017$ & 00006 & jaket bomber prapatan rebel & Jaket bomber & Prapatan rebel & penjualan & $\mathrm{Rp}$ & 135.000 & $10 \%$ & Rp 121.500 \\
\hline 14 & $01 / 11 / 2017$ & 00006 & kaos lengan panjang fake side & kaos panjang & fake side & penjualan & $\mathrm{Rp}$ & 90.000 & $10 \%$ & Rp 81.000 \\
\hline 15 & $02 / 11 / 2017$ & 00007 & kaos pendek fake side & kaos pendek & fake side & penjualan & $\mathrm{Rp}$ & 65.000 & $10 \%$ & Rp $\quad 58.500$ \\
\hline 16. & $02 / 11 / 2017$ & 00007 & celana pendek prapatan rebel & celana pendek & Prapatan rebel & penjualan & $\mathrm{Rp}$ & 80.000 & $10 \%$ & Rp 72.000 \\
\hline 17 & $02 / 11 / 2017$ & 00007 & kaos lengan panjang seventh angel & kaos panjang & seventh angel & penjualan & $\mathrm{Rp}$ & 90.000 & $10 \%$ & Rp 81.000 \\
\hline 18 & $02 / 11 / 2017$ & 00008 & kaos lengan panjang prapatan rebel & kaos panjang & Prapatan rebel & penjualan & $\mathrm{Rp}$ & 95.000 & $10 \%$ & Rp 85.500 \\
\hline 19 & $02 / 11 / 2017$ & 00008 & kaos pendek quiksilver & kaos pendek & quiksilver & penjualan & $\mathrm{Rp}$ & 95.000 & $10 \%$ & Rp 85.500 \\
\hline 20 & $02 / 11 / 2017$ & 00009 & kaos pendek memphis origin & kaos pendek & memphis origin & penjualan & $\mathrm{Rp}$ & 70.000 & $10 \%$ & Rp 63.000 \\
\hline 21 & $02 / 11 / 2017$ & 00009 & kaos lengan panjang seventh angel & kaos panjang & seventh angel & penjualan & $\mathrm{Rp}$ & 90.000 & $10 \%$ & Rp 81.000 \\
\hline 22 & $02 / 11 / 2017$ & 00010 & kaos pendek farodist & kaos pendek & farodist & penjualan & $\mathrm{Rp}$ & 75.000 & $10 \%$ & Rp 67.500 \\
\hline 23 & $02 / 11 / 2017$ & 00010 & Jaket hoody fucking enemy & Jaket hoody & fucking enemy & penjualan & $\mathrm{Rp}$ & 120.000 & $10 \%$ & Rp 108.000 \\
\hline 24 & $02 / 11 / 2017$ & 00011 & kaos lengan panjang prapatan rebel & kaos panjang & Prapatan rebel & penjualan & $\mathrm{Rp}$ & 95.000 & $10 \%$ & $\mathrm{Rp} \quad 85.500$ \\
\hline 25 & $02 / 11 / 2017$ & 00012 & kaos lengan panjang seventh angel & kaos panjang & seventh angel & penjualan & $\mathrm{Rp}$ & 90.000 & $10 \%$ & Rp 81.000 \\
\hline 26 & $02 / 11 / 2017$ & 00012 & kaos lengan panjang prapatan rebel & kaos panjang & Prapatan rebel & penjualan & $\mathrm{Rp}$ & 95.000 & $10 \%$ & Rp 85.500 \\
\hline 27 & $02 / 11 / 2017$ & 00013 & kaos pendek seventh angel & kaos pendek & seventh angel & penjualan & $\mathrm{Rp}$ & 70.000 & $10 \%$ & Rp $\quad 63.000$ \\
\hline 28 & $02 / 11 / 2017$ & 00013 & kaos pendek farodist & kaos pendek & farodist & penjualan & $\mathrm{Rp}$ & 75.000 & $10 \%$ & Rp $\quad 67.500$ \\
\hline 29 & $02 / 11 / 2017$ & 00014 & jaket bomber prapatan rebel & Jaket bomber & Prapatan rebel & penjualan & $\mathrm{Rp}$ & 135.000 & $10 \%$ & Rp 121.500 \\
\hline & NOVEMBE & $R 2017$ & DESEMBER2017 & Sheet3 & & & & & & (1) 4 \\
\hline
\end{tabular}

Dari data transaksi yang ada, tidak semua yang diolah, pada penelitian ini data yang digunakan hanya transaksi yang lebih dari 1 jenis barang, bukan berapa jumlah barang yang dibeli karena yang dicari adalah keterkaitan barang berikut hal-hal yang dilakukan dalam pengolahan data.

\subsubsection{Pemilihan Data yang diolah}

Data yang diolah yaitu transaksi yang lebih dari 1 jenis barang dan yang digunakan adalah No Struk dan jenis barang. Di tabel transaksi Penjualan ada beberapa variabel seperti "tanggal", "Nama barang", "Harga" dan lain-lain tetapi tidak semua variabel tersebut digunakan, yang diperlukan hanya variabel "No struk" dan "Jenis barang".

\subsubsection{Diskrisitasi variabel}

Pengolahan data dalam penilitan ini dibutuhkan teknik diskritasi. Teknik diskritasi adalah suatu cara yang yang dilakukan untuk memecahkan daerah perhitungan kedalam daerah-daerah kecil karena kolom pada penelitian ini memiliki range yang cukup luas. Aturan range ini dapat dirubah seperti apa yang dikehendaki oleh peneliti. Berikut adalah contoh beberapa nilai diskritasi variabel nama barang :

Tabel 2. Diskritisasi Variabel

\begin{tabular}{|c|c|l|}
\hline NO & Nilai Diskritasi & \multicolumn{1}{|c|}{ Nama barang } \\
\hline 1 & 1 & Kaos Lengan Panjang prapatan rebel \\
\hline 2 & 2 & Kaos Lengan Panjang fucking enemy \\
\hline 3 & 3 & Kaos Lengan Panjang seventh angel \\
\hline 4 & 4 & Kaos Lengan Panjang owa suport \\
\hline 5 & 5 & Kaos Lengan Panjang quiksilver \\
\hline 6 & 6 & Kaos Lengan Panjang memphis origin \\
\hline 7 & 7 & Kaos Lengan Panjang fake side \\
\hline 8 & 8 & Kaos Lengan Panjang farodist \\
\hline 9 & 9 & Kaos Lengan Panjang oroots \\
\hline 10 & 10 & Kaos Lengan Panjang Gangster \\
\hline
\end{tabular}




\begin{tabular}{|l|l|l|}
\hline 11 & 11 & Kaos Lengan Panjang DC \\
\hline 12 & 12 & Kaos Lengan Panjang vans \\
\hline 13 & 13 & Kaos Lengan Pendek prapatan rebel \\
\hline 14 & 14 & Kaos Lengan Pendek fucking enemy \\
\hline 15 & 15 & Kaos Lengan Pendek seventh angel \\
\hline 16 & 16 & Kaos Lengan Pendek owa suport \\
\hline 17 & 17 & Kaos Lengan Pendek quiksilver \\
\hline 18 & 18 & Kaos Lengan Pendek memphis origin \\
\hline 19 & 19 & Kaos Lengan Pendek fake side \\
\hline.. & $\mathrm{N}$ & n barang \\
\hline
\end{tabular}

\subsubsection{Format Tabular Data Transaksi}

Format data tabular yaitu pengubahan format data dari data primer yang berbentuk data penjualan dirubah menjadi data biner 1 dan 0 . Penkonversian ini dilakukan karena sehubungan sebuah aplikasi yang format database menggunakan Microsoft Excell dengan bentuk tabular data [20]. Proses konvrensinya yaitu nomor slip data yang akan diuji dibuat membentuk horizontal kebawah, dan semua jenis item akan menjadi attribute dalam bentuk vertikal menyamping. Contoh hasil pemindahan data tabular.

Tabel 3. Tabel Tabulasi

\begin{tabular}{|c|c|c|c|c|c|c|c|c|c|c|c|c|c|c|c|c|c|c|c|c|}
\hline $\operatorname{tr}$ & 1 & 2 & 3 & 4 & 5 & 6 & 7 & 8 & 9 & 10 & 11 & 12 & 13 & 14 & 15 & 16 & 17 & 18 & 19 & $\mathrm{n}$ \\
\hline 1 & 0 & 0 & 0 & 0 & 0 & 0 & 0 & 0 & 0 & 0 & 0 & 0 & 0 & 1 & 0 & 0 & 0 & 1 & 0 & 0 \\
\hline 2 & 0 & 0 & 0 & 0 & 0 & 0 & 0 & 0 & 0 & 0 & 1 & 0 & 0 & 0 & 0 & 0 & 0 & 0 & 0 & 0 \\
\hline 3 & 0 & 0 & 1 & 0 & 0 & 0 & 0 & 0 & 0 & 0 & 0 & 0 & 0 & 1 & 0 & 0 & 0 & 1 & 0 & 0 \\
\hline 4 & 0 & 0 & 0 & 0 & 0 & 0 & 0 & 0 & 0 & 0 & 0 & 0 & 0 & 0 & 1 & 0 & 0 & 0 & 0 & 0 \\
\hline 5 & 0 & 0 & 0 & 0 & 0 & 0 & 0 & 0 & 0 & 1 & 0 & 0 & 0 & 0 & 1 & 0 & 0 & 0 & 0 & 0 \\
\hline 6 & 0 & 0 & 0 & 0 & 0 & 0 & 0 & 0 & 0 & 0 & 0 & 0 & 0 & 0 & 0 & 1 & 0 & 0 & 0 & 0 \\
\hline 7 & 0 & 0 & 1 & 0 & 0 & 0 & 0 & 0 & 0 & 0 & 0 & 0 & 0 & 0 & 1 & 0 & 0 & 0 & 1 & 0 \\
\hline 8 & 1 & 0 & 0 & 0 & 0 & 0 & 0 & 0 & 0 & 0 & 0 & 0 & 0 & 0 & 0 & 0 & 1 & 0 & 0 & 0 \\
\hline 9 & 0 & 0 & 1 & 0 & 0 & 0 & 0 & 0 & 0 & 0 & 0 & 0 & 0 & 0 & 0 & 0 & 0 & 1 & 0 & 0 \\
\hline 10 & 0 & 0 & 0 & 0 & 0 & 0 & 0 & 0 & 0 & 0 & 1 & 0 & 0 & 0 & 0 & 0 & 1 & 0 & 0 & 0 \\
\hline 11 & 0 & 0 & 0 & 0 & 0 & 0 & 0 & 0 & 0 & 0 & 0 & 0 & 1 & 0 & 0 & 0 & 0 & 0 & 0 & 0 \\
\hline 12 & 1 & 0 & 1 & 0 & 0 & 0 & 0 & 0 & 0 & 0 & 0 & 0 & 0 & 0 & 0 & 0 & 0 & 0 & 0 & 0 \\
\hline 13 & 0 & 0 & 0 & 0 & 0 & 0 & 0 & 0 & 0 & 0 & 0 & 0 & 0 & 0 & 1 & 0 & 0 & 1 & 0 & 0 \\
\hline 14 & 0 & 0 & 0 & 0 & 0 & 0 & 0 & 0 & 0 & 0 & 0 & 0 & 0 & 0 & 0 & 0 & 0 & 1 & 0 & 0 \\
\hline 15 & 0 & 1 & 1 & 0 & 0 & 0 & 0 & 0 & 0 & 0 & 0 & 0 & 0 & 0 & 0 & 0 & 0 & 1 & 0 & 0 \\
\hline 16 & 0 & 0 & 0 & 0 & 1 & 0 & 0 & 0 & 0 & 0 & 0 & 0 & 0 & 0 & 0 & 0 & 0 & 0 & 0 & 0 \\
\hline 17 & 0 & 0 & 0 & 1 & 0 & 0 & 0 & 0 & 0 & 0 & 0 & 0 & 0 & 0 & 0 & 0 & 0 & 0 & 0 & 0 \\
\hline 18 & 0 & 0 & 0 & 0 & 1 & 0 & 0 & 0 & 0 & 0 & 0 & 0 & 0 & 0 & 0 & 0 & 1 & 0 & 0 & 0 \\
\hline 19 & 0 & 0 & 0 & 0 & 0 & 0 & 0 & 0 & 1 & 0 & 0 & 0 & 0 & 0 & 0 & 0 & 0 & 0 & 0 & 0 \\
\hline 20 & 0 & 0 & 0 & 0 & 0 & 0 & 0 & 0 & 0 & 0 & 0 & 1 & 0 & 0 & 0 & 0 & 1 & 0 & 0 & 0 \\
\hline
\end{tabular}


Dari tabel tabulasi dapat dilihat perhitungan per item dan di hasilkan data transaksi seperti ini :

Tabel 1. Data Itemset

\begin{tabular}{|l|l|}
\hline Transaksi & \multicolumn{1}{|c|}{ Items } \\
\hline 1 & $\{14,18\}$ \\
\hline 2 & $\{11\}$ \\
\hline 3 & $\{3,14,18\}$ \\
\hline 4 & $\{15\}$ \\
\hline 5 & $\{10,15\}$ \\
\hline 6 & $\{16\}$ \\
\hline 7 & $\{19,15,3\}$ \\
\hline 8 & $\{1,17\}$ \\
\hline 9 & $\{18,3\}$ \\
\hline 10 & $\{17,11\}$ \\
\hline 11 & $\{13\}$ \\
\hline 12 & $\{3,1\}$ \\
\hline 13 & $\{15,18\}$ \\
\hline 14 & $\{18\}$ \\
\hline 15 & $\{2,3,18\}$ \\
\hline 16 & $\{5\}$ \\
\hline 17 & $\{4\}$ \\
\hline 18 & $\{5,17\}$ \\
\hline 19 & $\{9\}$ \\
\hline 20 & $\{12\}$ \\
\hline & \\
\hline
\end{tabular}

\subsection{PreProcessing}

Pada tahap preprocesing dilakukan untuk membersihkan data-data yag tidak digunakan dalam pencarian dan data [7], yang digunakan untuk pencarian aturan asosiasi adalah data barang dan nama struk selanjutnya data diubah ke dalam bentuk tabular dengan isi binari 1 untuk data yang terjual dan 0 untuk data yang tidak terjual seperti terlihat pada Gambar 3.

\section{Tabel 5. Data Preprocesing}

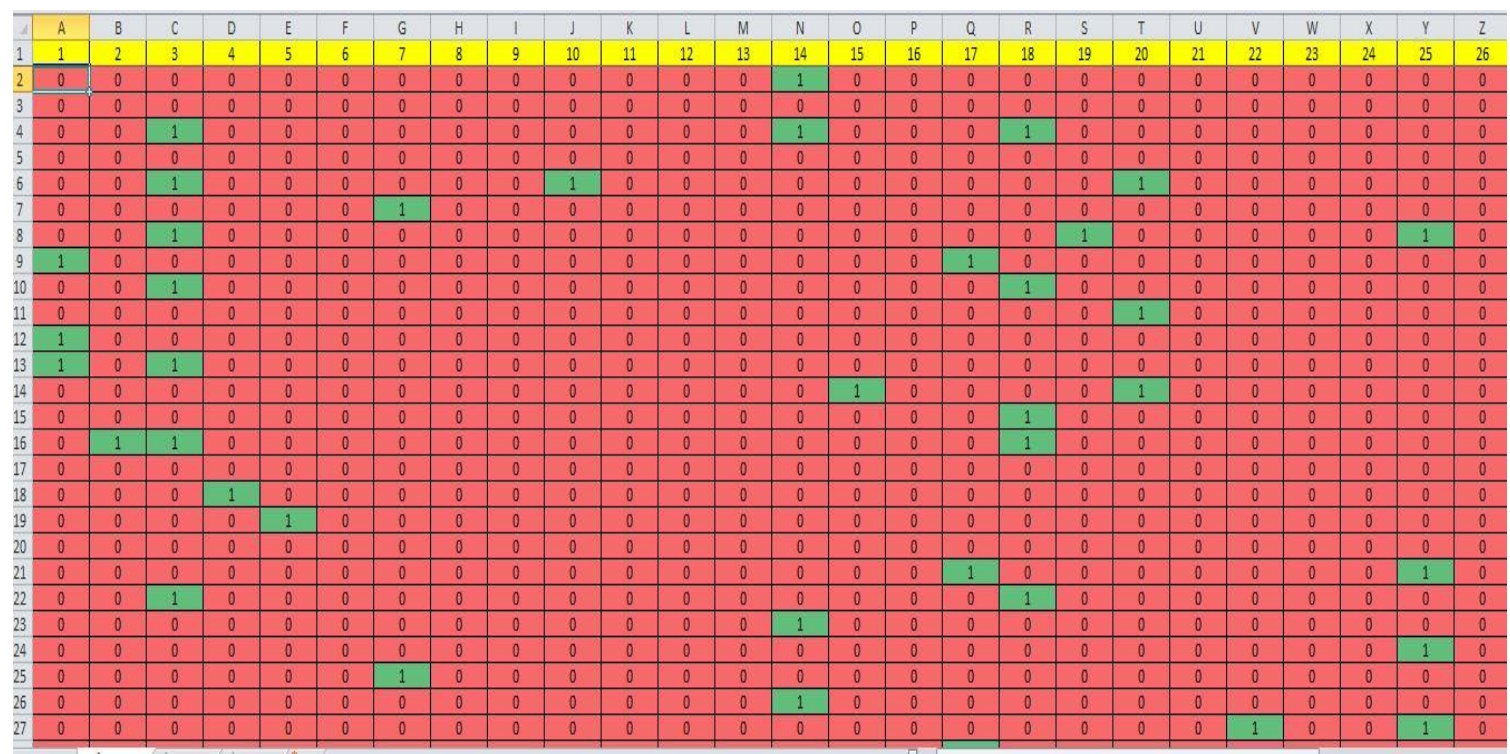




\subsection{Apriori}

Dalam mencari penggunaan apriori hal pertama yang harus dilakukan adalah menentukan minimum support dan menghitung minimum support dengan rumus [8]

$$
\text { Support, } s(X \rightarrow Y)=\frac{\sigma(X \cup Y)}{N}
$$

Dalam rumus diatas $\sigma$ merupakan support dari item $\mathrm{X}$ dan $\mathrm{Y}$ yang ditemukan dari data dan $\mathrm{N}$ merupakan jumlah transaksi. Setelah menghitung minimum support sampai iterasi terakhir yang ditemukan pada data selanjutnya menentukan nilai confidence dan untuk mencari nilai confidence digunakan rumus

$$
\text { Confidence, } c(X \rightarrow Y) \frac{\sigma(X \cup Y)}{\sigma X}
$$

Dalam rumus diatas $\sigma$ merupakan nilai support dari $\mathrm{X}$ dan $\mathrm{Y}$ dan di bagi nilai support dari $\mathrm{X}$

\subsection{FP-Growth}

Dalam pencarian asosiasi dengan FP-Growth merupakan pengembangan dari apriori pada FPGrowth untuk mencari nilai confidence dan support masih sama hanya saja peredaannya di FPGrowth hanya menggunakan 1 iterasi dan memiliki 3 tahapan yaitu tahap pembangkitan confidentional pattern base, tahap conditional FP-Tree dan tahap pencarian frequen itemset dengan menggunakan TID (Transaction Identity) [9].

\subsection{Evaluasi}

Pada pencarian Asosiasi kevalidan dari sebuah aturan yang digunakan adalah menggunakan metode lift ratio, lift ratio sendiri biasa digunakan sebagai penentu aturan asosiasi valid atau tidak valid, aturan asosiasi dikatakan valid apabila nilai lift ratio dalam aturan asosiasi tersebut benilai $>1$ dan semakin banyak nilai lift ratio yang dimiliki aturan asosiasi maka akan lebih bagus untuk mencari lift ratio dapat di temukan dengan rumus [10]

$$
\begin{aligned}
& \text { Lift Ratio }=\frac{\text { Confidence }(A \cap B)}{\text { Expected Confidence }} \\
& \text { Expected Confidence }=\frac{\sum \text { Transaksi Mengandung } Y}{\sum \text { Transaksi }}
\end{aligned}
$$

\subsection{Hasil Evaluasi Tertinggi}

Pada hasil evaluasi tertinggi merupakan hasil dari perbandingan hasil lift ratio tertinggi [11] dan algoritma yang memiliki lift ratio tertinggi adalah algoritma yang bagus dalam pencarian aturan asosiasi.

\subsection{Pembentukan Aturan Asosiasi}

Pembentukan aturan asosiasi merupakan hasil dari aturan asosiasi akhir yang memiliki lift ratio tertinggi [12].

\section{HASIL DAN PEMBAHASAN}

Didalam penelitian ini akan dlakukan aturan asosiasi yaitu dengan aturan minimum confidence 0,9 atau $90 \%$ dan minimum support 0,01 atau $1 \%$ didapatkan hasil berikut

\subsection{FP-Growth}

Pada aturan FP-Growth dengan minimum confidence 0,9 dan minimum support 0,1 ditemukan 24 aturan asoisasi seperti pada gambar 4 . 


\section{AssociationRules}

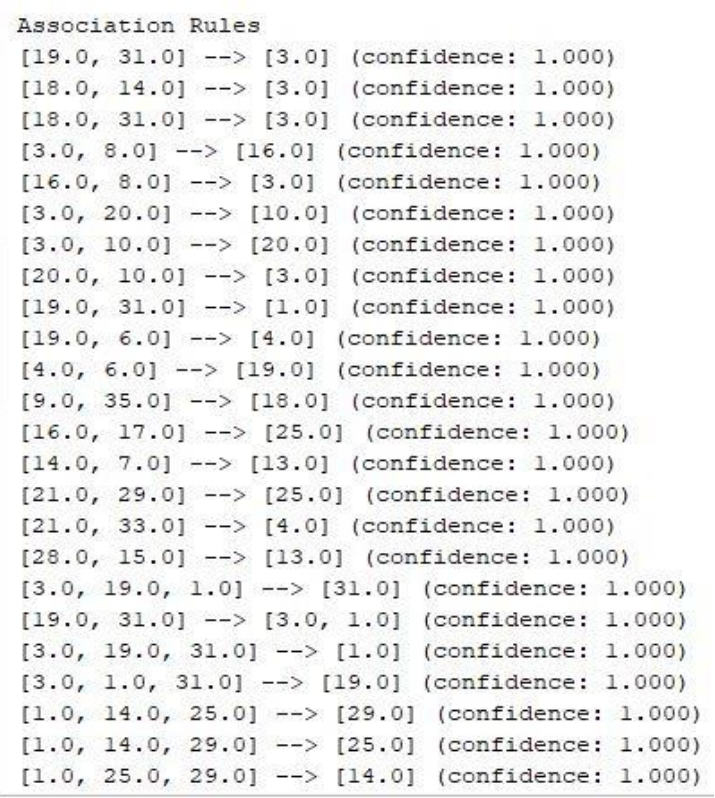

\section{Gambar 2. Hasil FP-Growth}

\subsection{Apriori}

Pada aturan asosiasi yang ditemukan oleh algoritma apriori dengan minimum confidence 0,9 dan minimum support 0,1 ditemukan 10 aturan asosiasi seperti pada gambar 5 .

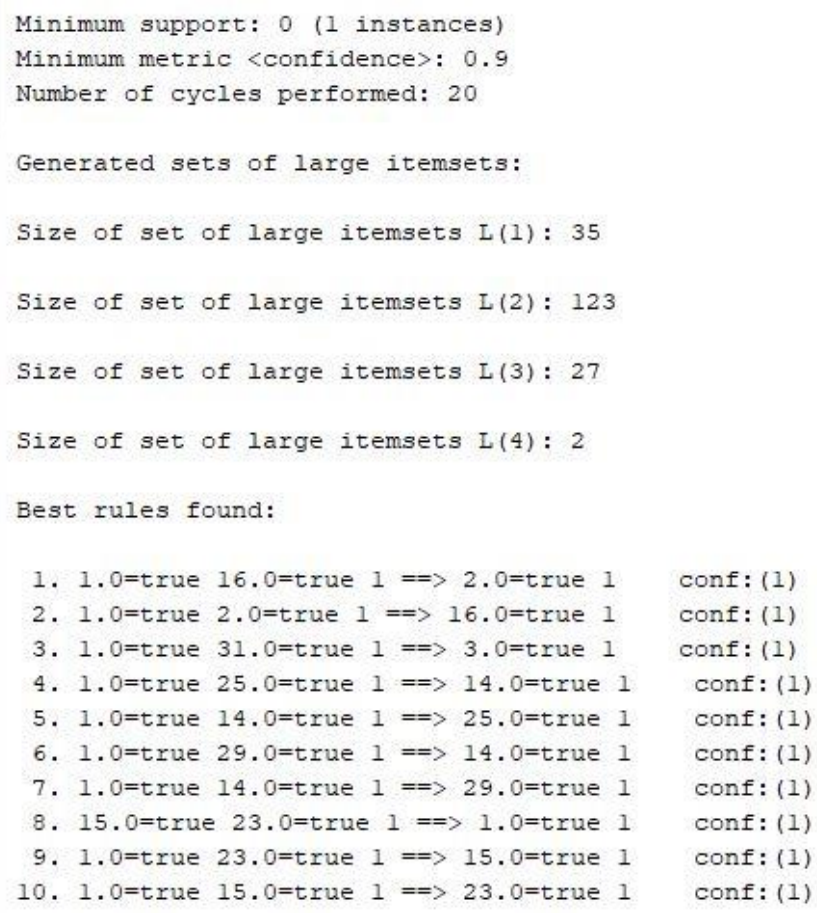

\section{Gambar 3. Hasil Apriori}




\subsection{Lift Ratio}

Dari perhitungan ke dua algoritma didapatkan hasil lift ratio seperti terlihat pada tabel 1.

Tabel 6. Perbandingan Lift Ratio

\begin{tabular}{|c|c|c|c|c|c|}
\hline \multicolumn{3}{|c|}{ Apriori } & \multicolumn{3}{c|}{ FP-Growth } \\
\hline Itemset & conclusion & Lift ratio & Itemset & conclusion & Lift ratio \\
\hline$\{1,16\}$ & $\{2\}$ & 27,675 & $\{19,31\}$ & $\{3\}$ & 13,488 \\
\hline$\{1,2\}$ & $\{16\}$ & 24,065 & $\{18,14\}$ & $\{3\}$ & 13,488 \\
\hline$\{1,31\}$ & $\{3\}$ & 13,500 & $\{18,31\}$ & $\{3\}$ & 13,488 \\
\hline$\{1,25\}$ & $\{14\}$ & 24,065 & $\{3,8\}$ & $\{16\}$ & 24,043 \\
\hline$\{1,14\}$ & $\{25\}$ & 26,357 & $\{16,8\}$ & $\{3\}$ & 13,488 \\
\hline$\{1,29\}$ & $\{14\}$ & 24,065 & $\{3,20\}$ & $\{10\}$ & 33,515 \\
\hline$\{1,14\}$ & $\{29\}$ & 36,900 & $\{3,10\}$ & $\{20\}$ & 29,105 \\
\hline$\{15,23\}$ & $\{1\}$ & 19,768 & $\{20,10\}$ & $\{3\}$ & 13,488 \\
\hline$\{1,23\}$ & $\{15\}$ & 24,065 & $\{19,31\}$ & $\{1\}$ & 19,750 \\
\hline$\{1,15\}$ & $\{23\}$ & 46,125 & $\{19,6\}$ & $\{4\}$ & 27,650 \\
\hline- & - & - & $\{4,6\}$ & $\{19\}$ & 16,265 \\
\hline- & - & - & $\{9,35\}$ & $\{18\}$ & 19,404 \\
\hline- & - & - & $\{16,17\}$ & $\{25\}$ & 26,333 \\
\hline- & - & - & $\{14,7\}$ & $\{13\}$ & 28,359 \\
\hline- & - & - & $\{21,29\}$ & $\{25\}$ & 26,333 \\
\hline- & - & - & $\{21,33\}$ & $\{4\}$ & 27,650 \\
\hline- & - & - & $\{28,15\}$ & $\{13\}$ & 28,359 \\
\hline- & - & - & $\{3,19,1\}$ & $\{31\}$ & 29,892 \\
\hline- & - & - & $\{19,31\}$ & $\{3,1\}$ & 553 \\
\hline- & - & - & $\{3,19,31\}$ & $\{1\}$ & 19,750 \\
\hline- & - & - & $\{3,1,31\}$ & $\{19\}$ & 16,265 \\
\hline- & - & - & $\{1,14,25\}$ & $\{29\}$ & 27,650 \\
\hline- & - & - & $\{1,14,29\}$ & $\{25\}$ & 26,333 \\
\hline- & - & - & $\{1,25,29\}$ & $\{14\}$ & 24,043 \\
\hline
\end{tabular}

Pada tabel perbandingan hasil lift ratio yang terbesar didapat oleh algoritma FP-Growth dengan nilai 553 yang ditemukan pada aturan $\{19,31\} \rightarrow\{3,1\}$ yang berarti produk 19 dan 31 dapat diletakkan berdampingan dengan produk 3 dan 1. Sehingga algoritma FP-Growth adalah algoritma yang paling baik dibandingkan algoritma apriori karena dari hasil aturan yang ditemukan lebih banyak serta hasil lift ratio yang di dapat juga lebih besar dibandingkan milik apriori.

\section{KESIMPULAN}

Dari hasil perbandingan algoritma Apriori dan FP-Growth untuk mencari pola asosiasi terhadap penataan barang dengan menggunakan data penjualan bulan November, Desember 2017 dan Januari 2018 yang telah penulis lakukan maka dapat ditarik kesimpulan sebagai berikut:

a. FP-Growth dapat menemukan aturan asosiasi lebih banyak dari pada Apriori karena proses pada FP-Growth yang tidak membutuhkan beberapa iterasi pada prosesnya sehingga aturan asosiasi yang di dapat lebih banyak.

b. Diantara kedua algoritma asosiasi rule algoritma FP-Growth memiliki tingkat ke akurasian lebih besar dari pada apriori. 
c. Proses dari algoritma FP-Growth lebih cepat dari pada algoritma apriori.

d. Dari proses relasi setiap produk yang sudah di temukan melalui proses pencarian association rule dapat digunakan untuk mengatur tata letak yang dapat meningkatkan kualitass penjualan terhadap toko distro Epo Store.

\section{SARAN}

Penelitian ini telah menghasilkan hasil asosiasi dengan jumlah kevalidan rule yang tinggi dari perbandingan ke dua algoritma association rule untuk tata letak barang di toko distro Epo Store namun untuk penelitian selanjutnya masih memerlukan pengembangan dalam beberapa hal yakni:

a. Menggunakan data set yang lebih lama rentang waktunya seperti 1 tahun atau 2 tahun ke belakang.

b. Menggunakan algoritma asosiasi lain ataupun penggabungan beberapa algoritma lain untuk dapat menemukan aturan asosiasi yang lebih efisien dan efektif.

c. Menggunakan data dari data penjualan terbaru untuk mendapatkan hasil yang update untuk lebih memudahkan pengelola Epo tore dalam melakukan strategi penjualan.

d. Mengimplimentasikan kedalam aplikasi sehingga pihak epo store dapat menggunakan aplikasi tersebut untuk bisa mengetahui pola asosiasi pada data transaksi sebelumnya.

\section{DAFTAR PUSTAKA}

[1] A. Chandra, "Peningkatan Performa Algoritma Apriori Untuk Aturan Asosiasi Data Mining," dalam Seminar Nasional Teknologi Informasi dan Multimedia, Yogyakarta, 2017.

[2] M. Iqbal dan Muatin, "Analisa Keranjang Belanja Konsumen Pada Data Penjualan Bulan Ramadhan Menggunakan Algoritma Apriori (Studi Kasus : Citro Coffepark Clothes Pekanbaru)," dalam Seminar Nasional Teknologi Informasi, Komunikasi dan Industri(STNKI), Riau, 2017.

[3] S. Shukla, B.K.Mohanty dan A. Kumar, "A Multi Attribute Value Theory approach to rank association rules leveraging better bussines decision making," ScieneDirect, vol. I, no. 16, pp. 1031-1038, 2017.

[4] D. P. Larasati, S. M. Muhammad Nasrun dan S. Umar Ali Ahmad, "Analysis and Implementation of FP-Growth Algorithm In Smart Application to Detemine Market Basket Analysis on Retail Bussiness (Case Study: PT. X)," dalam e-proceding of engineering, Bandung, 2015.

[5] F. Mohamad, R. S. Kemas dan A. Ibnu, "Penerapan Metode Association Rule Menggunakan Algoritma Apriori Pada Simulasi Prediksi Hujan Wilayah Kota Bandung," JITTER ( Jurnal Ilmiah Teknlogi informasi Terapan, vol. II, no. 10, pp. 221-227, April 2016.

[6] T. T. Yu dan K. T. Lynn, "Proposed Method for Modified Apriori Algorithm," Information and Knowledge Engineering, pp. 68-73, 2017.

[7] A. Anas, "Apriori Algorithm Use for A Consumer Behavior in The Purchase of Goods," Jurnal Sains dan Informatika, vol. I, no. 10, pp. 45-59, 2015.

[8] P. N. Utari dan R. F. Hakim, "Penerapan Metode Association Rule Menggunakan Algoritma Apriori Untuk Analisa Pola Data Kecelakaan Pesawat dari Tahun 1967-2014 di Indonesia," dalam Prociding Seminar Nasional Matematika dan pendidikan Matematika UMS, Jakarta, 2015.

[9] Amrin, "Data Mining Dengan Algoritma Apriori untuk Penentuan Aturan Asosiasi Pola Pembelian Pupuk," Paradigma, vol. XIX, no. 8, pp. 74-79, Maret 2017.

[10] E. Nurelasari, "Algoritma Asosiasi K-Means dan FP-Growth Untuk Analisis Keranjang Pasar Pada Penjualan Produk Alumunium," Information Management for Education And Profesionals, pp. 179-186, 2017.

[11] I. Djamaludin dan A. Nursikuwagus, "Analisis Pola Pembelian Konsumen Pada Transaksi Penjualan Menggunakan Algoritma Apriori," Jurnal SIMETRIS, vol. 8, no. 11, pp. 671-678, November 2017.

[12] W. A. Triyanto, V. Suhartono dan H. Himawan, "Analisis Keranjang Pasar Menggunakan KMedoids dan FP-Growth,” Pseudocode, vol. II, no. 17, pp. 129-142, September 2014. 